Pesq. Vet. Bras. 36(6):539-544, junho 2016 DOI: $10.1590 / \mathrm{S} 0100-736 \mathrm{X} 2016000600013$

\title{
Movement anatomy of the gluteal region and thigh of the giant anteater Myrmecophaga tridactyla (Myrmecophagidae: Pilosa) ${ }^{1}$
}

\author{
Priscilla Rosa Queiroz Ribeiro ${ }^{2 *}$, André Luiz Quagliatto Santos² ${ }^{2}$ Lucas de Assis \\ Ribeiro $^{2}$, Tharlianne Alici Martins de Souza ${ }^{2}$, Daniela Cristina Silva Borges ${ }^{2}$, \\ Rogério Rodrigues de Souza ${ }^{2}$ and Saulo Gonçalves Pereira ${ }^{2}$
}

\begin{abstract}
Ribeiro P.R.Q., Santos A.L.Q., Ribeiro L.A., Souza T.A.M., Borges D.C.S., Souza R.R. \& Pereira S.G. 2016. Movement anatomy of the gluteal region and thigh of the giant anteater Myrmecophaga tridactyla (Myrmecophagidae: Pilosa). Pesquisa Veterinária Brasileira 36(6):539-544. Laboratory for Teaching and Research on Wild Animals (LAPAS), Federal University of Uberlândia, Rua Piauí s/n, Umuarama, Uberlândia, MG 38405-317, Brazil. E-mail: priscillarqr@yahoo.com.br

Locomotion reveals the displacement and behavior manner of the species in their daily needs. According to different needs of the several species, different locomotor patterns are adopted. The shapes and attachment points of muscles are important determinants of the movements performed and consequently, the locomotion and motion patterns of living beings. It was aimed to associate anatomical, kinesiology and biomechanics aspects of the gluteal region and thigh of the giant anteater to its moving characteristics and locomotor habits. It was used three specimens of Myrmecophaga tridactyla, settled in formaldehyde aqueous solution at $10 \%$ and subsequently, dissected using usual techniques in gross anatomy. The morphological characteristics of the gluteal region and thigh that influence the patterns of movement and locomotion of animals, were analyzed and discussed in light of literature. All muscles of the gluteal region and thigh of giant anteater show parallel arrangement of the muscular fibers, being flat or fusiform. These muscles are formed in the joint which the interpotent type biolever act. These morphological characteristics indicate a greater predominance of amplitude and movement speed at the expense of strength. On the other hand, features such as osteometric index and the observation of giant anteater motion indicate the opposite, what reflects this animal lack of expertise in locomotor habits and shows the need of future realization of more detailed studies in this subject.
\end{abstract}

INDEX TERMS: Locomotion, kinesiology, biomechanics, giant anteater, Myrmecophaga tridactyla, Pilosa.

RESUMO.- [Anatomia do movimento da região glútea e coxa de Myrmecophaga tridactyla tamanduá-bandeira (Myrmecophagidae: pilosa).] A locomoção revela o modo de deslocamento e comportamento das espécies nas suas necessidades diárias. De acordo com as diferentes necessidades das diversas espécies, diferentes padrões locomotores são adotados. As formas e pontos de fixação dos músculos são importantes determinantes dos movimentos realizados e, por conseguinte, dos padrões de locomoção

\footnotetext{
${ }^{1}$ Received on December 8, 2015.

Accepted for publication on March 17, 2016.

${ }^{2}$ Laboratory for Teaching and Research on Wild Animals (LAPAS), Federal University of Uberlândia (UFU), Rua Piauí, s/n, Umuarama, Uberlândia, MG 38405-317, Brazil. Master's research supported by FAPEMIG. *Corresponding author: priscillarqr@yahoo.com.br
}

e movimentação dos seres vivos. Objetivou-se associar aspectos anatômicos, cinesiológicos e biomecânicos da região glútea e coxa do tamanduá bandeira às suas características de movimentação e hábitos locomotores. Utilizaram-se três espécimes de Myrmecophaga tridactyla, fixados em solução aquosa de formaldeído a $10 \%$ e posteriormente, dissecados usando as técnicas usuais em anatomia macroscópica. As características morfológicas da região glútea e coxa que influenciam os padrões de movimento e locomoção dos animais foram analisadas e discutidas à luz da literatura. Todos os músculos da região glútea e coxa do tamanduá bandeira apresentam disposição paralela das fibras musculares, sendo planos ou fusiformes. Esses músculos formam nas articulações sobre as quais agem bioalavancas do tipo interpotente. Essas características morfológicas indicam maior predominância de amplitude e velocidade 
de movimento em detrimento da força. Por outro lado, características como os índices osteométricos e a observação da movimentação do tamanduá bandeira indicam o oposto, o que reflete a falta de especialização desse animal quanto aos hábitos locomotores e sinaliza a necessidade da realização futura de estudos mais detalhados a esse respeito.

TERMOS DE INDEXAÇÃO: Locomoção, cinesiologia, biomecânica, tamanduá-bandeira, Myrmecophaga tridactyla, Pilosa.

\section{INTRODUCTION}

The giant anteater belongs to Myrmecophagidae family that has three subspecies, and they are found in southeastern Mexico, Central and South America (Nowak 1999). Solitary, silent and peaceful nature, in the wild, they are always alone, except in mating season or mother offspring, while in captivity they accept living together. Giant anteaters have anatomical, behavioral and physiological adaptations concerned to feeding, which is consisted of ants, termites and their eggs, and the larvae of beetles. They have long skull, tube like and long muzzle, relatively small eyes and ears, a very long portable tongue, developed salivary glands and they have no teeth (Medri 2003).

Specie of the Pilosa order, the giant anteater is listed as a potentially vulnerable animal to extinction by the International Union for Conservation of Nature and Natural Resources (IUCN 2011). Myrmecophaga tridactyla extinction threat is mainly due to destruction of habitats in order to give place to pastures and monocultures, fires, poaching and roadkill (Takami et al 1998).

Locomotion reveals the displacement and behavior manner of the species in their daily needs such as feeding, mating and escape (Densmore 1983). This way, according to the different needs of the several species, different locomotor patterns are adopted. According to Oliveira (2001) the Myrmecophagidae do not have expertise about the locomotor habit. Instead, they show a mix of anatomical and structural features related to various types of adaptation, such as terrestrial, climbing and digging. The giant anteater walks with clenched fists and with the lateral portion and nodes of the hands joints on the ground. When it feels in danger, its natural reaction is to flee, gallopping somewhat disorderly, fighting only if forced, when then it uses its powerful claws.

Toledo (1998) states that the variations of the locomotor system are responsible for the locomotion diversity observed in modern mammals. For Oliveira (2001) morphological changes are related to the limbs mechanical ability and, consequently, it reflects on the functionality on the performance of biological roles, such as obtaining food, defense and locomotion.

The shapes and attachment points of the muscles in the bones are important determinants of movements performed in the different joints and therefore are determinants of the locomotion and motion patterns of living beings. So, knowing motion anatomy aspects, as well as kinesiology and basic biomechanics aspects, such as muscular fibers shape and arrangement, points of muscles origin and insertion, biolever types, strength arms and resistance and mechanical advantage of body segments, becomes crucial to understanding the animal movement. This article aimed to associate the anatomical, kinesiology and biomechanics aspects of the gluteal region and thigh of giant anteater to its moving characteristics and locomotor habits.

\section{MATERIALS AND METHODS}

It was used three male adult specimens of Myrmecophaga tridactyla Linnaeus (1758) that belong to the didactic and scientific collections of Laboratory for Teaching and Research on Wild Animals (LAPAS), from Federal University of Uberlândia (UFU) and from the Laboratory of Anatomy of Federal University of Goiás Campus Catalão (UFG). This study was approved by the Ethics Committee on Animal use of UFU (Protocol 039/11) and it is in accordance with Normative Instruction $03 / 2015$ of IBAMA.

The animals used were settled in formaldehyde aqueous solution at $10 \%$ and then preserved immersed in opaque vats containing the same concentration of solution. Their preparation for analysis followed the anatomical conventional techniques proposed by Rodrigues (2005).

The basic kinesiology and biomechanics aspects observed were the form and fascicular arrangement of the muscles of gluteal region and thigh, and the set up biolever systems in the hip and knee joints. The influences of these characteristics in the movement and locomotion patterns of the animals were analyzed and discussed in accordance with the proposals of Tortora \& Grabowski (2010) for these characteristics.

\section{RESULTS AND DISCUSSION}

The giant anteater gluteal region consists of these muscles, $\mathrm{m}$. gluteus superficiallis, $\mathrm{m}$. gluteus medius, $\mathrm{m}$. gluteus profundus, $\mathrm{m}$. gemelli, $\mathrm{m}$. quadrates femoral and $\mathrm{m}$. obturator internus (Table 1 and Figure 1). The thigh muscles are $\mathrm{m}$. tensor fasciae latae, $\mathrm{m}$. biceps femoris, $\mathrm{m}$. semitendinosus, $\mathrm{m}$. semimembranosus, $\mathrm{m}$. abductor cruris caudalis, m. gracillis, $\mathrm{m}$. pectineus, $\mathrm{m}$. quadriceps femoris, $\mathrm{mm}$. brevis longus and magnus adductors and $\mathrm{m}$. sartorius (Table 2 and Figure 2).

Table 1. Attachment points of the gluteal region muscles of giant anteater

\begin{tabular}{ll}
\hline Muscle & \multicolumn{1}{c}{ Origin } \\
\hline $\begin{array}{l}\text { M. Gluteus superficiallis } \\
\text { M. Gluteus medius }\end{array}$ & $\begin{array}{l}\text { Lateral sacral crest, crest. sacrotuberous ligament and iliac } \\
\text { Gluteal surface of ilium and iliac crest. } \\
\text { Ilium body. }\end{array}$ \\
$\begin{array}{ll}\text { M. Gemelli } \\
\text { M. Quadratus femoris }\end{array}$ & $\begin{array}{l}\text { Side surface of the ilium body, caudal to gluteus profundus. } \\
\text { Ventral side of the ilium up to the ischial tubercle. Medial surface } \\
\text { of the greater trochanter of the femur distal to the twin. } \\
\text { Pubis and ischium, at the medial side edge of the } \\
\text { obturator foramen. Greater trochanter of the femur. }\end{array}$
\end{tabular}




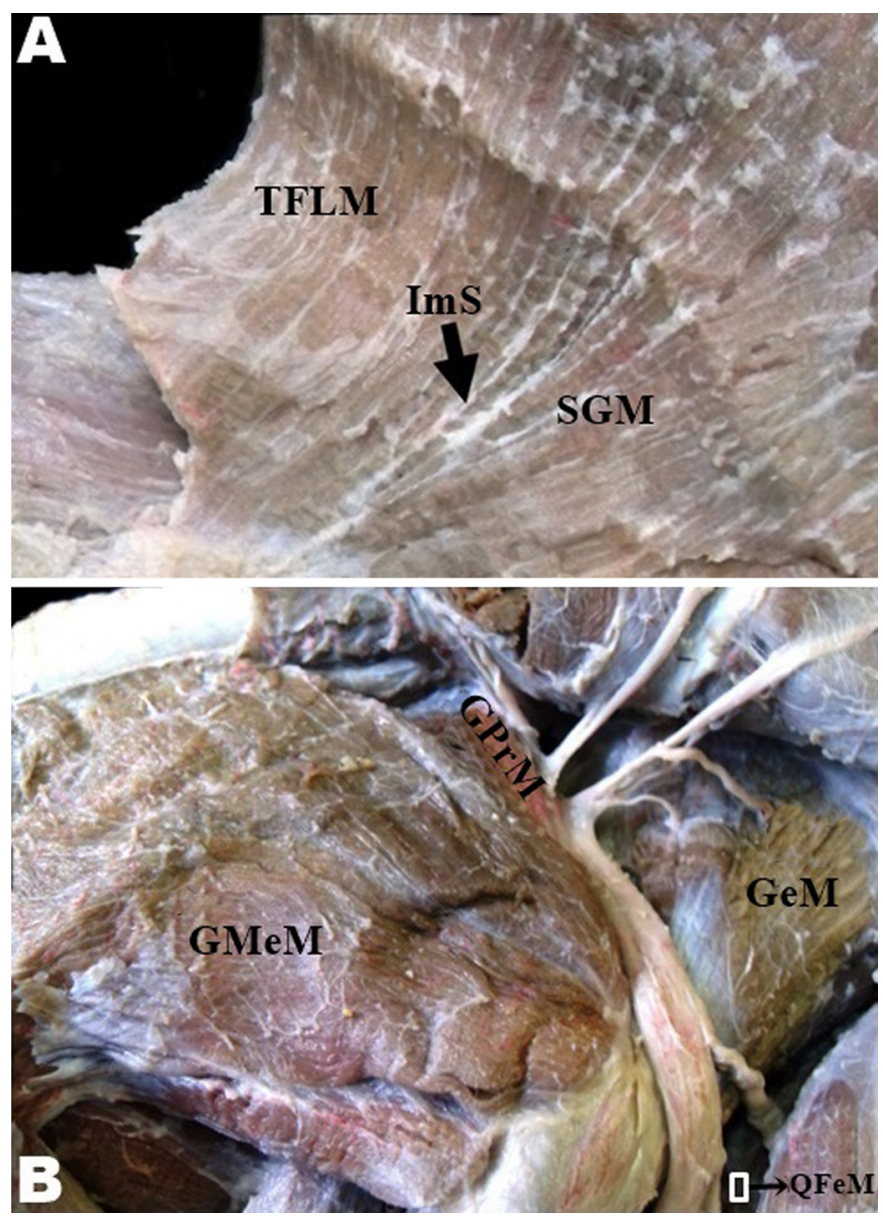

Fig.1. Photography of the gluteal region muscles of giant anteater. A - superficial side view: SGM, superficiallis gluteus muscle; ImS, intermuscular septum; TFLM, tensor fasciae latae muscle; B - deep side view: GeM, gemelli muscle; GMeM, gluteus medius muscle (far for better visualization of the deep muscles); GPrM, gluteus profundus muscle; MQFe, quadratus femoris muscle.
All the muscles of the gluteal region and thigh of the giant anteater show parallel arrangement of the muscle fibers, and they are or flat or fusiform. According to Tortora \& Grabowski (2010) the fascicular disposition represents an important role in the balance between strength and movement amplitude. Lieber \& Bodine-Fowler (1993) state that all muscles are made up of muscular fibers, and, the length and orientation of them have a considerable effect on muscular function. The relationship between muscle architecture and muscular function is that the excursion (how much the muscle can shorten) and this shortening velocity is proportional to the length of the fiber, while the strenght is proportional to the total physiological cross-sectional area of muscular fibers.

Through the shape and arrangement of the fibers of the giant anteater muscles, it infers that this animal shows greater amplitude and movement speed and lower strenght, since the muscles with fibers parallel arrangement, as those found in the gluteal region and thigh of the giant anteater, when compared to penniform muscle fibers, show a lower amount of fascicles that span the entire length of the muscle, generating, thus, broader and faster movements with less strenght. This way, Hildebrand \& Goslow (2006) point out that the maximum strenght a muscle can exert, is equal to the contraction strength of its fibers, multiplied by the total number of fibers.

The muscles of the gluteal region and thigh of the giant anteater form in the joint and over them act interpotent type biolevers. Figure 3 shows the muscular insertion regions, in other words, the point of strenght application of these muscles, as well as the point of resistance, illustrating the type of established biolevers. Such kind of biolever found, also suggests predominance of amplitude and movement speed at the expense of strength, since the point of strenght application (muscular insertion) is closer to the rotation axis (joint) than the resistance (the body segment

Table 2. Attachment points of the giant anteater thigh muscles

\begin{tabular}{|c|c|c|}
\hline Muscle & Origin & Insertion \\
\hline M. Tensor fasciae latae & Thigh tuberosity. & $\begin{array}{l}\text { Fasciae latae and through this muscle into the } \\
\text { lateral condyle of the tibia and fibular head. }\end{array}$ \\
\hline M. Biceps femoris & Ischial tuberosity. & $\begin{array}{l}\text { Cranial part: fasciae latae and through this muscle in the } \\
\text { proximal part of the crural fasciae. Caudal part: middle } \\
\text { third of the crural fascia and common calcaneal tendon. }\end{array}$ \\
\hline M. Semitendinosus & Ischial tuberosity. & $\begin{array}{l}\text { Middle skull surface of the medial third of the } \\
\text { tibia body and common calcaneal tendon. }\end{array}$ \\
\hline M. Semimembranosus & $\begin{array}{l}\text { The two parts in the ischial tuberosity and the } \\
\text { caudal part in part of the pelvic symphysis. }\end{array}$ & $\begin{array}{l}\text { Caudal part: proximal surface and medial skull of the } \\
\text { tibia body. Cranial part: medial condyle of the tibia. }\end{array}$ \\
\hline M. Abductor cruris caudalis & Ischial tuberosity, common to semitendinous. & Middle part of the fasciae crural. \\
\hline M. Quadriceps femoris & Retus femoris: acetabular caudal tuberosity. & Tibial tuberosity. \\
\hline
\end{tabular}

\section{Gracilis}

M. Adductor brevis

M. Adductor longus

M. Adductor magnus

M. Pectineus

M. Sartorius
Retus femoris: acetabular caudal tuberosity.

Vastus medialis: medial surface of the femur body.

Vastus lateralis: lateral surface of the femur body.

Vastus intermedius: lateral surface of the femoral body, common to the vastus lateralis

Superior pubis ramus and pelvic symphysis, caudal pubic ramus.

Ischial ramus, close to the pelvic symphysis. Ischial ramus, close to the pelvic symphysis.

Ischial ramus, close to the pelvic symphysis. Superior pubis ramus.

Thigh tuberosity.
Fasciae latae and through this muscle into the proximal part of the crural fasciae Caudal part: middle third of the crural fascia and common calcaneal tendon. Middle skull surface of the medial third of the tibia body and common calcaneal tendon. Tibial tuberosity.

Medial skull surface of the middle third of the tibia body and common calcaneal tendon.

Medial surface of the middle third of the femur. Medial part: medial and caudal surface and distal to femoral body. Lateral side: medial femoral epicondyle. Side surface to the lateral epicondyle of the femur. Middle surface of the medial third of the femur, distal to the adductor brevis.

Cranial surface of the tibia. 

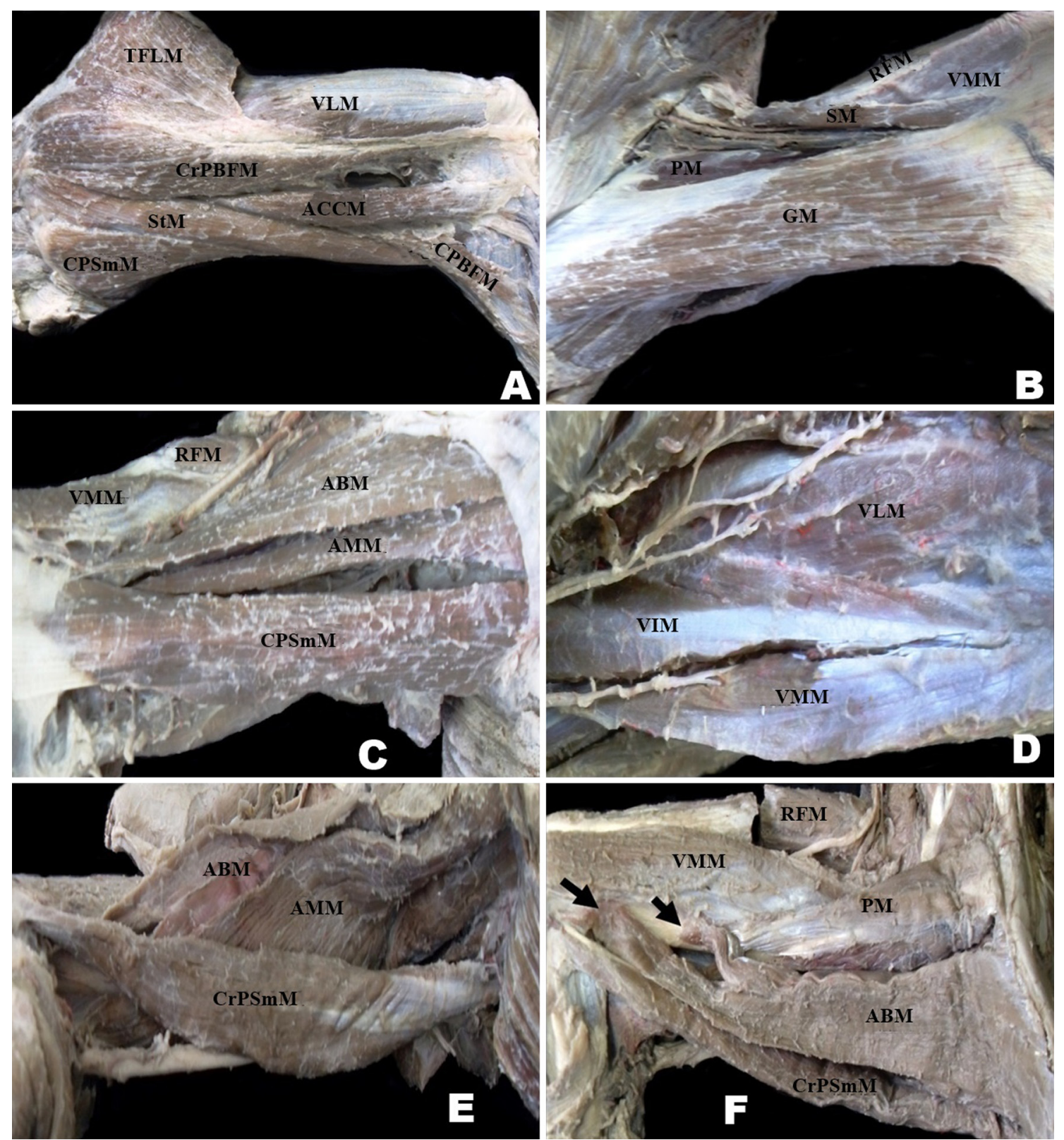

Fig.2. Photograph of the giant anteater thigh muscles. A - superficial side view: TFLM, tensor fasciae latae muscle; VLM, vastus lateralis muscle; CrPBFM, cranial part of the biceps femoris muscle; ACCM, abductor cruris caudalis muscle; StM, semitendinosus muscle; CPSmM, caudal part of the semimembranosus muscle; CPBFM, caudal part of the biceps femoris muscle; B - superficial medial view: GM, gracilis muscle; PM, pectineus muscle; SM, sartorius muscles; RFM, rectus femoris muscle; VMM, vastus medialis muscle; C deep caudal-medial view: RFM, rectus femoris muscle; VMM, vastus medialis muscle; ABM, adductor brevis muscle; AMM, adductor magnus muscle; CPSmM, caudal part of the semimembranosus muscle; D - deep cranial view: VLM, vastus lateralis muscle; VIM, vastus intermedius muscle; VMM, vastus medialis muscle; E - deep medial view: ABM, adductor brevis muscle; AMM, adductor magnus muscle; CrPSmM, cranial part (deep) of the semimembranosus muscle; F - deep medial view: RFM, rectus femoris muscle; VMM, vastus medialis muscle; PM, pectineus muscle; ABM, adductor brevis muscle (bicaudal); CrPSmM, cranial part of the semimembranosus muscle.

and / or external resistance), forming interpotent biolevers, which, according to Tortora \& Grabowski (2010) favor the amplitude and the movement speed, with loss of strength.

The interpotent joints are the most commonly found in the limbs. This type of biolever causes mechanical disadvantage because it has a greater resistance arm and smaller arm strength. According to Clair (1986) the proximal muscle insertion in the bone end, indicates greater excursion to the distal surface of the bone, as well as speed in the movement, when the opposite occurs, we observe slower and less extended activity with high tension levels.

In contrast to what is shown in this study, where the morphological characteristics analyzed indicate a greater predominance of amplitude and movement speed at the expense of strength, a study by Oliveira (2001), using osteometric index, pointed strength emphasis at the expense of speed, indicating the use of slower but more vigorous mo- 


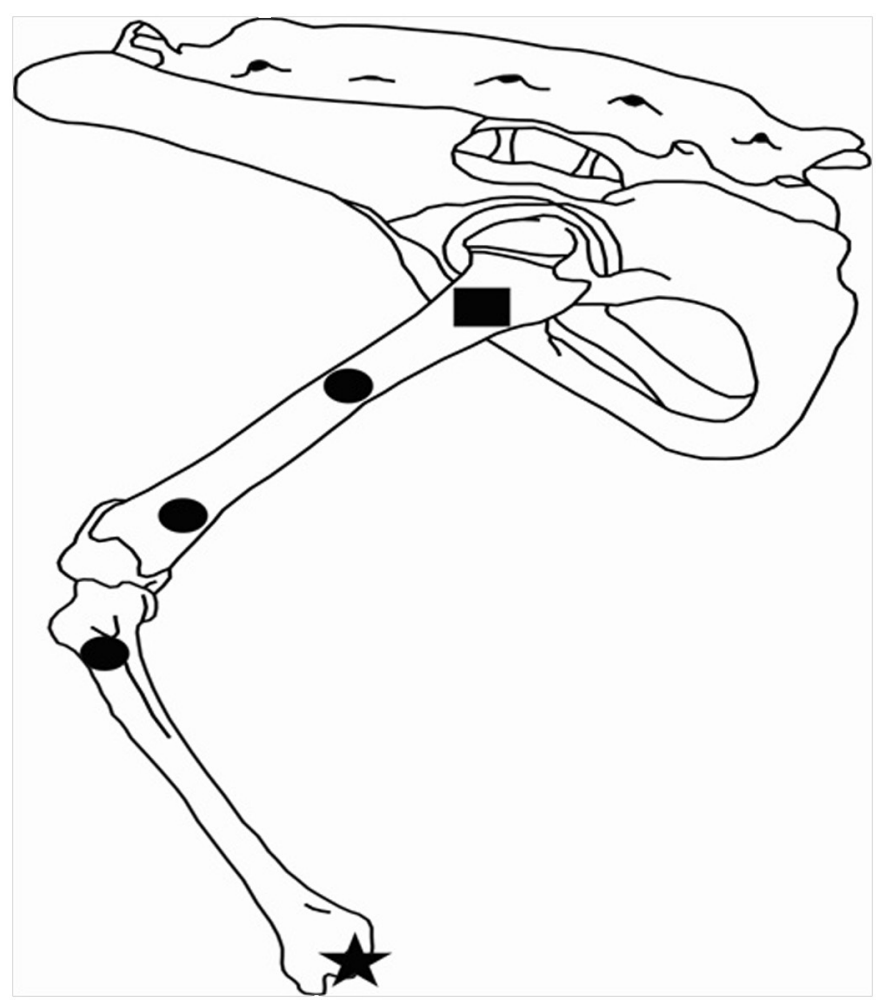

Fig.3. Schematic drawing of the strenght application points of the gluteal region and thigh muscles and point of resistance in giant anteater. Rectangle, insertion region of the muscles of the gluteal region; Circle, insertion regions of the thigh muscles; Star, resistance point.

vements. This shown divergence in relation to movements of the hind limbs of the giant anteater when using different morphological characteristic as a source of information, may reflect the lack of expertise of these animals about locomotor habit, and they show anatomical characteristics related to various types of adaptation, such as terrestrial, climbing and digging, as indicated by the same author.

Observing the motion of the giant anteater we notice that it has slow movements. Since this animal also has morphological characteristics that favor the amplitude and movement speed, it infers that this slowness in carrying out movements may occur mostly due to its large size and eating habits with low calories, having low metabolic rate and body temperature, than the morphological characteristics of the limbs themselves.

According to Hildebrand (1995) the structure of the body and the locomotion manner, are closely related to energetic. According to Ribeiro (2006) the metabolic cost increases linearly with the increasing speed, and the metabolic waste to move a gram of body mass during certain distance, decreases with increased body mass. Since the metabolic rate and body mass factors may influence the locomotion, the locomotor movement patterns of the giant anteater are possibly influenced by low metabolic rate and the great body mass presented by this animal.

In this sense Naples (1999) states that the giant anteater feeding habit affects not only its mastication and digestive structures, but also the behavior, metabolic rate and locomotor function. Medri \& Mourão (2005) state that food limitation seems to influence the giant anteater activity patterns, as well as its movements.

Although it has predominantly slow movements, Gambaryan et al. (2009) state that the giant anteater is able of gallopping, although running is a secondary adaptation for these animals, as evidenced by the greater proportion of muscles in the forelimbs compared to pelvic. Farley \& Taylor (1991 apud Ribeiro, 2006) state that the quadrupeds walk at low speeds, trot at moderate speeds and gallop at higher speeds, so the giant anteater capacity of galloping indicates its ability to perform movements at high speeds, although it is not the most common in its locomotor pattern.

Another inference that can be made based on the morphology of the muscles of the gluteal region and thigh of the giant anteater is that a greater quantity and dimension, and consequently greater contractile capacity of the extensor muscles of the thigh in relation to flexor muscles, is what, along with the changes of the lumbar spine of this animal, described by Endo (2009), allows it to assume, in some situations, a bipedal posture, being supported on the hind limbs and tail, what, according to Alho (1993) is a feature that distinguish the Xenarthras.

Two groups are responsible for conducting the hip extension, the gluteal muscles which are: the m. gluteus superficiallis, $m$. gluteus medius, $m$. gemelli and $m$. quadrates femoral that operate in this movement; and the ischium pubic-group of the thigh muscles, the muscles participating in this movement are: $\mathrm{m}$. biceps femoris, m. semimembranosus, $\mathrm{m}$. semitendinosus, $\mathrm{m}$. abductor cruris caudalis, m. gracilis and $\mathrm{m}$. adductor magnus. These different groups have muscular insertion, and therefore they show points of strength application in different regions of the limbs, so they also have different adaptations to the movement (Figure 3).

According to Oliveira (2001), in the case of the gluteal group, there is a greater adaptation for the performance of rapid movements, what is more important at the final of the animal start, to promote an increase in speed; while the ischium-pubic group is better adapted to more vigorous but slower movements, what is more important at the beginning of locomotion during start, when the movement is slower and resistance is greater. This way, once again it is evident the diversity of movements features that can be performed by the limbs of giant anteater.

The presence of characteristics that indicate speed and movement amplitude presented in this study, while other features, such as osteometric index show prevalence of strenght in the giant anteater moving, they reflect the lack of expertise of this animal on its locomotor habits and sign the need of future performance of more detailed studies in this subject.

\section{CONCLUSION}

The morphological characteristics identified and analyzed in this study, muscles with parallel arrangement of fibers and interpotent biolevers demonstrate favoring of the amplitude and movement speed at the expense of strength. 
Acknowledgements.- The authors thank Lucélia Gonçalves Vieira, for her contribution in the illustration work, and Zenon Silva and Daniela Cristina de Oliveira Silva for the cession of material and physical space for the research.

\section{REFERENCES}

Alho C.J.R. Distribuição da fauna num gradiente de recursos em mosaico. In: Pinto M.N. (org.), Cerrado: caracterização, organização e perspectivas. Brasília: UNB, 1993. p. 213-262.

Clair L.E. 1986. Miologia Geral, p. 134. In: Getty R. (Ed.), Anatomia dos animais domésticos. 5a ed. Interamericana, Rio de Janeiro.

Densmore L.D. 1983. Biochemical and immunological systematic of the order Crocodilia, p.397-465. In: Hecht M.K., Wallace B. \& Prance G.H. (Eds), Evolutionary Biology.

Endo H., Komiya T., Kawada S., Hayashida A., Kimura J., Itou T., Koie H. \& Sakay T. 2009. Three-dimensional reconstruction of the xenarthrous process of the thoracic and lumber vertebrae in the giant anteater. Mammal Study, 34(1):1-6.

Gambaryan P.P., Zherebtsova O.V., Perepelova E.A. \& Platonov V.V. 2009. Pes muscles and their action in giant anteater Myrmecophaga tridactyla (Myrmecophagidae, Pilosa) compared with other plantigrade mammals. Russian Journal of Theriology, 8(1):1-15.

Hildebrand M. 1995. Análise da estrutura dos vertebrados. Atheneu, São Paulo.

Hildebrand M. \& Goslow J.R. 2006. Análise da estrutura dos vertebrados. $2^{\underline{a}}$ ed. Atheneu, São Paulo.

IUCN - International Union for Conservation of Nature and Natural Resources. IUCN Red List of Threatened Species. 2011. Disponível em: <http://www.iucnredlist.org>. Acesso em: 27 out. 2015.
Lieber R.L. \& Bodine-Fowler S.C. 1993. Skeletal muscle mechanics: implications for rehabilitation. Physical Therapy, 12(73):844-56.

Medri I.M. \& Mourão G. 2005. Home range of giant anteaters (Myrmecophaga tridactyla) in the Pantanal wetland, Brazil. Journal of Zoology, 266:365-375.

Medri I.M. 2003. Dieta de Tamanduá-bandeira (Myrmecophaga tridactyla) no Pantanal da Nhecolândia, Brasil. no 5 Edentata, p.29-34.

Naples V.L. 1999. Morphology, evolution and function of feeding in the giant anteater (Myrmecophaga tridactyla). Journal of Zoology, 249:19-41.

Nowak R.M. 1999. Walker's Mammals of the World. 6th ed. The Johns Hopkins University Press, Baltimore and London.

Oliveira M.F. 2001. Morfologia funcional e desenho corporal da cintura pélvica e membros posteriores dos tamanduás (Mammalia: Xenarthra: Myrmecophagidae). Dissertação (Mestrado em Ciências Biológicas) Universidade Federal do Pará, Belém. 90f.

Ribeiro M.C.P. 2006. Correlação entre parâmetros cinemáticos da locomoção terrestre e energética em Cebus apella (macaco-prego). Tese (Doutorado em Ciências, na área de Fisiologia) - Instituto de Biociências, Universidade de São Paulo, São Paulo. 177 f.

Rodrigues H. 2005. Técnicas Anatômicas. 3aㅡ ed. Arte visual, Vitória.

Takami K., Yoshida M., Yosuida Y. \& Kojima Y. 1998. Sex determination in Giant Anteater (Myrmecophaga tridactyla) using hair roots by polymerase chain reaction amplification. Journal of Reproduction and Development, 44(1):73-78.

Toledo P.M. 1998. Locomotory patterns within the Pleistocene Sloths. Museu Paraense Emílio Goeldi, Belém, Pará. (Coleção Friedrich Katzer)

Tortora G.J., Grabowski S.R. 2010. Princípios de Anatomia e Fisiologia. 9a ed. Guanabara Koogan, Rio de Janeiro. 